\title{
Fertilization Rate and Placement Effects on Areca Palms Transplanted from Containers or a Field Nursery
}

\author{
Timothy K. Broschat and Kimberly A. Moore
}

\begin{abstract}
Areca palms (Dypsis lutescens [(H. Wendl.) Beentje and J. Dransf.]) were transplanted from containers or a field nursery and were treated with fertilizer placed at the bottom of the planting hole, incorporated into the backfill, or on the surface of the root ball to determine the effects of fertilizer placement at planting on palm growth and quality. Fertilizer was applied at $0,250 \mathrm{~g}(20 \mathrm{~g} \mathrm{~N})$, or $500 \mathrm{~g}(40 \mathrm{~g} \mathrm{~N})$ per tree for each placement method to determine fertilization rate effects. Areca palms transplanted from containers grew best when fertilizer was incorporated into the backfill, but any fertilizer placement or rate was better than no fertilizer. When areca palms were transplanted from a field nursery, there was no consistently best fertilizer placement method. However, fertilized plants grew better and had less severe nitrogen and potassium deficiency symptoms than unfertilized palms. There was no benefit to higher fertilization rate for either container- or field-grown areca palms.

Key Words. Areca; Dypsis lutescens; Nitrogen Deficiency; Plant Establishment; Potassium Deficiency; Root Growth.
\end{abstract}

Fertilization at the time of transplanting trees is a common practice with practitioners who believe that enhanced nutrient availability will accelerate the rate of establishment. However, studies have shown that responses to fertilization at the time of transplanting vary considerably according to species, native soil fertility, type of fertilizer used, and whether the trees were bare root, balled and burlapped, or containergrown. Where soils have adequate fertility, newly transplanted trees may not respond to fertilization (Shoup et al. 1981; Perry and Hickman 1992). Day and Harris (2007) and Harris et al. (2008) similarly found no response to fertilization in several tree species in infertile soil and compacted soils. Positive growth responses to fertilization at planting were noted by Broschat and Moore (2010), Gilman (1987), Gilman et al. (2000), Hensley et al. (1988), and Jacobs et al. (2005).

Response to fertilization at the time of planting may be affected by fertilizer placement. Hensley et al. (1988) found no differences in the growth response of transplanted container-grown Magnolia grandiflora when fertilizer was surface-applied, placed in the bottom of the planting hole, or incorporated into the backfill, but any fertilization was superior to no fertilization. Containergrown and field-grown trees may also respond differently due to the effects of organic potting substrate components, such as pine bark on nitrogen $(\mathrm{N})$ requirements (Schulte and Whitcomb 1975). Although Broschat and Moore (2010) examined the effects of $\mathrm{N}$ fertilization on transplanted container-grown palms, there are no published research studies on fertilizer placement effects for transplanted palms. The purpose of this study was to determine the effects of fertilizer placement and rate at the time of transplanting on the growth and quality of transplanted container-grown and field-grown areca palms (Dypsis lutescens).

\section{MATERIALS AND METHODS}

Areca palms were transplanted into a Margate fine sand soil in Davie, Florida, U.S. (265'1.7'N latitude, $80^{\circ} 14^{\prime} 15.2^{\prime \prime} \mathrm{W}$ longitude). This soil had a mean $\mathrm{pH}$ of 5.1 , cation exchange capacity of $7.5 \mathrm{cmol} / \mathrm{kg}$, and contained about $5 \%$ organic matter (A \& L Southern Labs, Deerfield Beach, Florida, U.S.). On September 29, 2009 (Experiment 1), 42 areca palms ca. $250 \mathrm{~cm}$ tall were transplanted from $23 \mathrm{~L}$ containers into $61 \mathrm{~cm}$ diameter holes spaced $4.5 \mathrm{~m}$ apart on centers. On October 2, 2009, 42 fieldgrown areca palms ca. $240 \mathrm{~cm}$ tall with $46 \mathrm{~cm}$ diameter root balls were similarly transplanted. Palms were fertilized at the time of transplanting with one of the following application methods: 1) incorporation into the backfill, 2) layering on the bottom of the planting hole, or 3) surface application by uniformly spreading the fertilizer over the root ball and backfilled area. For each application method employed, fertilizer was applied at three rates: 1) no fertilizer, 2) $250 \mathrm{~g}(=20 \mathrm{~g} \mathrm{~N})$ per tree, or 3) $500 \mathrm{~g} \mathrm{(=40} \mathrm{g}$ $\mathrm{N})$ per tree. The fertilizer used had a three-month release rate and an analysis of $8 \mathrm{~N}-0.9 \mathrm{P}-10 \mathrm{~K}-4 \mathrm{Mg}$ plus micronutrients with controlled released $\mathrm{N}$ from sulfur-coated urea, controlled release $\mathrm{K}$ from sulfur-coated potassium sulfate, and controlled release Mg from kieserite (Nurserymen's Sure Gro, Vero Beach, Florida, U.S.). As is standard maintenance practice for palms transplanted into field nurseries or landscapes in Florida (Broschat 2011), all palms, including those receiving no fertilizer at transplant, were fertilized by broadcasting this same $8 \mathrm{~N}-0.9 \mathrm{P}-10 \mathrm{~K}-4 \mathrm{Mg}$ fertilizer uniformly over the $1 \mathrm{~m}^{2}$ area surrounding each palm at a rate of $250 \mathrm{~kg} / 1000 \mathrm{~m}^{2}\left(=20 \mathrm{~kg} \mathrm{~N} / 1000 \mathrm{~m}^{2}\right)$ every three months for one year beginning at three months after transplanting.

The experimental design was a randomized complete block with three blocks of two replicate palms per treatment and block. Blocks of field-grown and container-grown palms were alternated 
within the planting field. This experiment was repeated with planting dates of March 9 and 10, 2010 (Experiment 2), for containergrown and field-grown palms, respectively. All palms received approximately $15 \mathrm{~mm}$ of water from overhead irrigation every other day for the first six weeks and every third day thereafter.

Overall palm height, as measured to the tip of the tallest vertically-extended leaf, was measured at the time of transplanting and at 3, 6, and 12 months thereafter. Growth was calculated as the height at three months minus initial height, height at six months minus initial height, and so forth. At those sampling dates, palms were subjectively rated for severity of $\mathrm{N}$ and $\mathrm{K}$ deficiencies on a 1 to 5 scale $(1=$ extremely deficient, $5=$ no visible symptoms of nutrient deficiency). Nitrogen deficiency symptoms included yellow to orange petiole and rachis coloration and discolored leaflets, while $\mathrm{K}$ deficiency primarily caused leaflet tip necrosis on the oldest leaves in this species (Elliott et al. 2004). At 16 weeks after transplanting, the southern half of the root system of each palm was manually excavated with all roots severed at the point of emergence from the original root ball. Since container-grown and fieldgrown palms appeared to have different vertical root distribution patterns, harvested roots were separated into two categories in the second experiment: those originating in the top 15 $\mathrm{cm}$ of the soil, and those originating deeper than $15 \mathrm{~cm}$ from the soil surface. All roots were rinsed clean, dried at $65^{\circ} \mathrm{C}$, and weighed. All data were analyzed by Analysis of Variance with mean separations by the Waller-Duncan k-ratio method.

\section{RESULTS}

In general, transplant source (container-grown versus fieldgrown) significantly affected shoot growth rates and root dry weights (Table 1; Table 2). Therefore, data from each transplant source were analyzed separately. There was also a significant transplant source $\times$ fertilizer rate effect on shoot growth rate for most sampling tissues in both experiments (Table 1).

In Experiment 1, fertilizer placement had no effect on shoot growth of areca palms transplanted from containers at 3, 6, and 12 months (Table 1); but at 6 and 12 months, Experiment 2 palms receiving fertilizer incorporated into the backfill had grown significantly more than those with fertilizer placed at the bottom of the planting hole. For palms transplanted from a field, plant shoot growth at three months in Experiment 1 was significantly greater when fertilizer was incorporated into the backfill than when applied at the bottom of the planting hole or as a surface application. However, fertilizer placement had no effect on palm shoot growth at 6 or 12 months in Experiment 1 or at any time in Experiment 2.

Fertilizer rate significantly affected palm shoot growth for transplanted container-grown areca palms in both experiments at 3 and 6 months and also at 12 months in Experiment 2

Table 1. Shoot growth of transplanted container-grown and field-grown areca palms with fertilizer applied at three locations and at three rates.

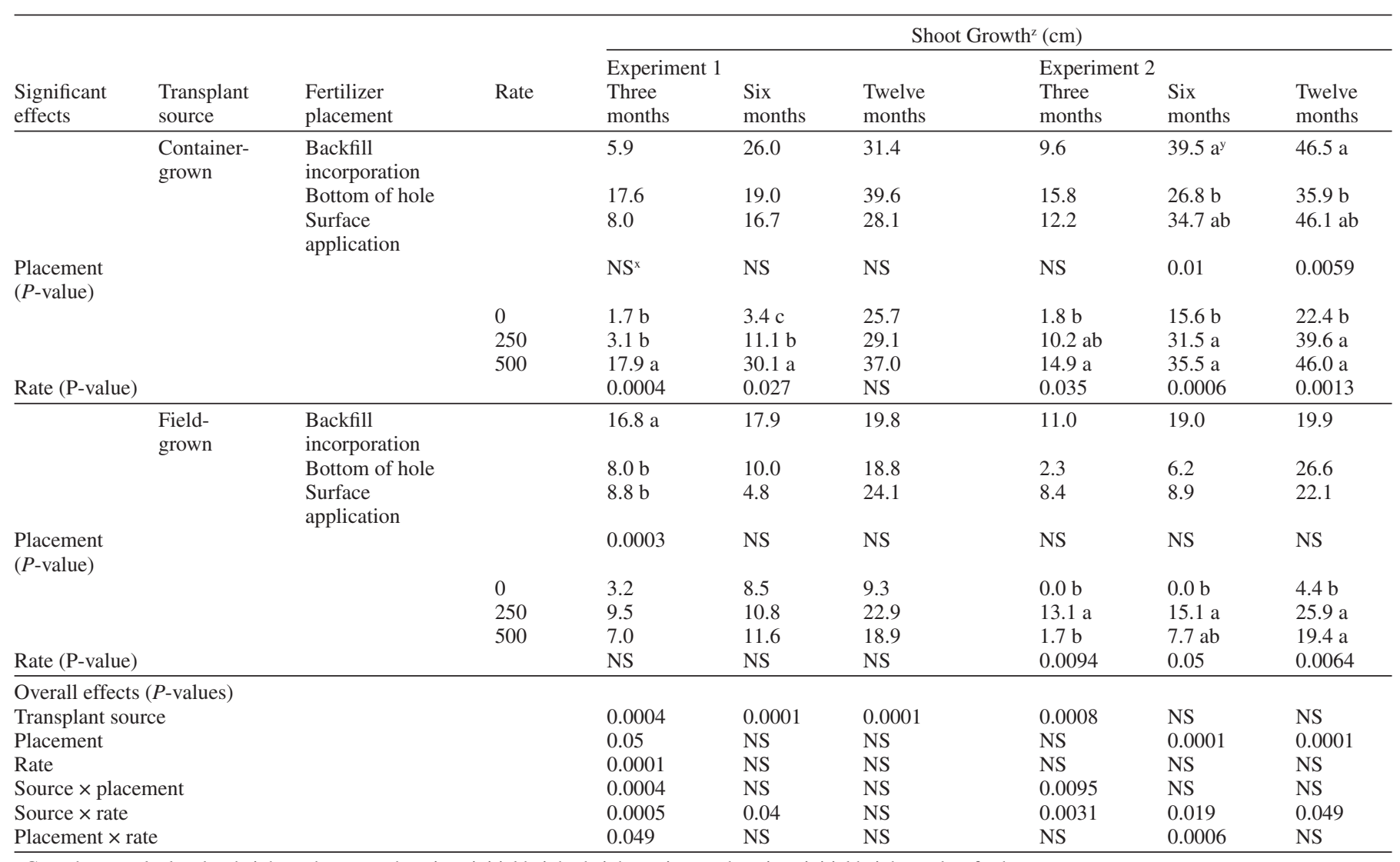

${ }^{\mathrm{z}}$ Growth was calculated as height at three months minus initial height, height at six months minus initial height, and so forth.

${ }^{y}$ Mean separation within columns and fertilizer placement and rate groupings by the Waller-Duncan k-ratio method, $P=0.05$.

${ }^{x}$ Non-significant. 
Table 2. Root dry weights of areca palms transplanted from containers or a field nursery with fertilizer applied at three locations and rates.

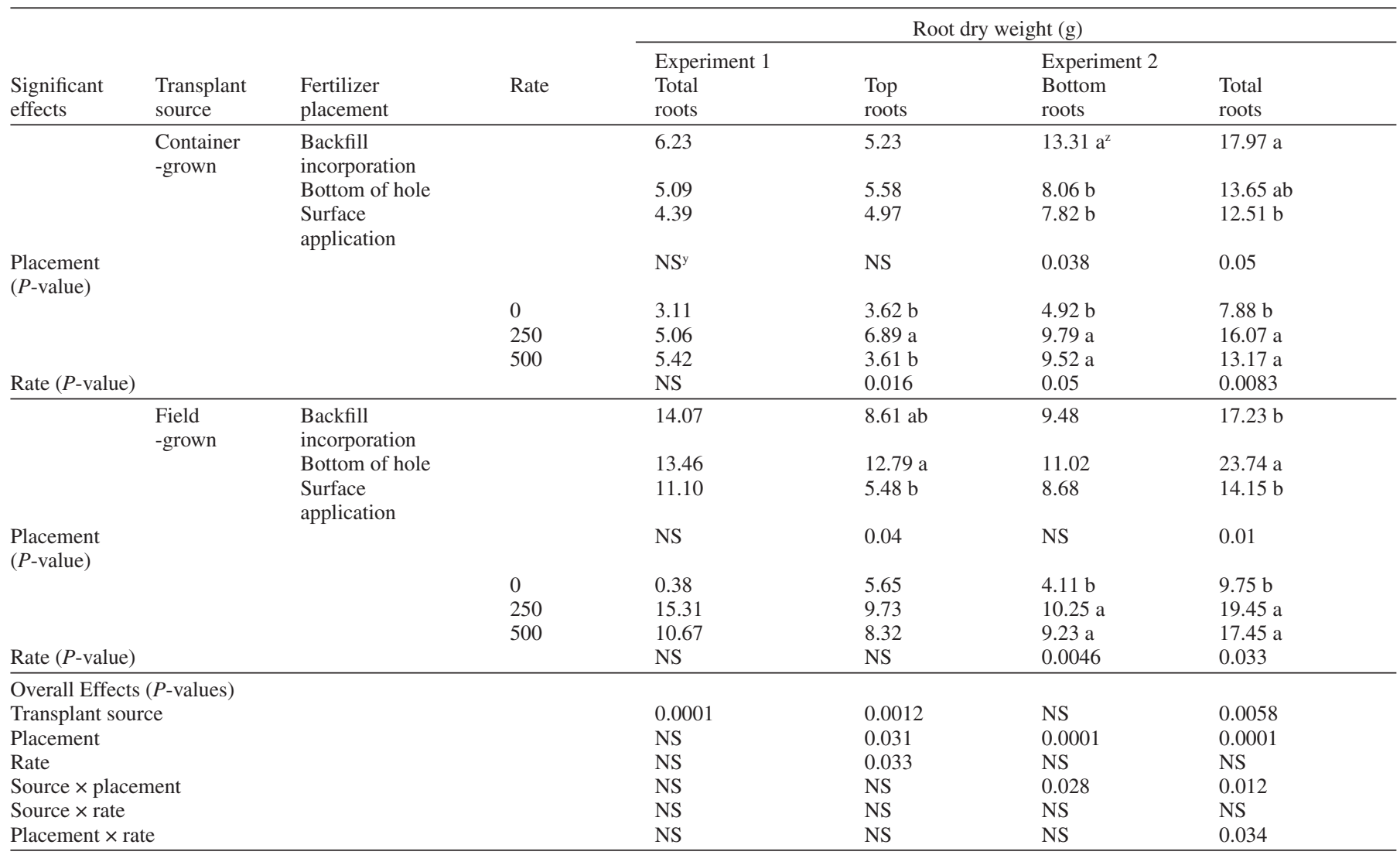

${ }^{2}$ Mean separation within columns and fertilizer placement and rate groupings by the Waller-Duncan k-ratio method, $P=0.05$

y Non-significant.

(Table 1). The highest fertilizer rate consistently resulted in greater growth than unfertilized palms. Palms fertilized at the low rate also grew significantly more than unfertilized control palms at 6 and 12 months after transplant in Experiment 2. For palms transplanted from a field, fertilization rate had no effect on palm growth in Experiment. 1, but in Experiment 2, palm shoot growth rate was consistently greater for the low fertilizer rate than for unfertilized palms (Table 1).

Neither container-grown nor field-grown areca palm roots responded to either fertilizer placement or rate in Experiment 1 (Table 2). While excavating root systems in Experiment.1, researchers observed that container-grown palms tended to have more of their roots concentrated at the bottom of the root ball, whereas field-grown palm roots were more uniformly distributed between upper and lower parts of the root ball. For that reason, roots in Experiment 2 were separated into those found in the upper $15 \mathrm{~cm}$ of the root ball or those found below $15 \mathrm{~cm}$ in depth.

For container-grown palms in Experiment 2, fertilizer placement had no effect on dry weight of roots found in the upper $15 \mathrm{~cm}$, but for deeper roots, backfill incorporation of fertilizer resulted in significantly greater root weight than either bottom of the hole or surface application (Table 2). Total root dry weight was greater for backfill-incorporated fertilized palms than for those receiving surface applications. Palms receiving backfill-incorporated fertilizer had significantly more of their roots in the lower portion of the root ball than in the top $15 \mathrm{~cm}$ of the soil compared to those fertilized by other methods. Fertilizer application rate significantly affected top, bottom, and total root dry weights for containergrown palms, with the low rate consistently resulting in greater root weights than unfertilized controls. The higher fertilization rate provided no additional benefit to container-grown palm roots.

Fertilizer placement affected top and total root dry weights, but not bottom root dry weights or root distribution pattern in field-grown areca palms in Experiment 2 (Table 2). Placing fertilizer at the bottom of the planting hole resulted in significantly greater top and total root dry weights than other fertilizer placement methods. Fertilization rate significantly affected bottom and total root dry weights, but there were no differences between the low and high fertilizer rates.

Neither fertilizer placement nor rate had any effect on $\mathrm{N}$ and $\mathrm{K}$ deficiency ratings for palms transplanted from containers in either experiment (data not shown). For palms transplanted from a field, $\mathrm{K}$ deficiency ratings were significantly higher for palms fertilized at the bottom of the planting hole than surface applied at 6 and 12 months after transplanting in Experiment 2 (Table 3), but no placement effects were observed in Experiment 1 (data not shown). At twelve months, fertilization at the bottom of the planting hole also produced better $\mathrm{K}$ deficiency ratings than backfill-incorporated fertilizer in Experiment 2. Fertilization rate had no effect on either $\mathrm{K}$ or $\mathrm{N}$ deficiency ratings in Experiment 1 (data not shown), but it significantly affected both $\mathrm{N}$ and $\mathrm{K}$ deficiency ratings in Experiment 2 on most sam- 
Table 3. Nitrogen and potassium deficiency severity ratings for Experiment 2 areca palms transplanted from a field nursery with fertilizer applied at three locations and at three rates.

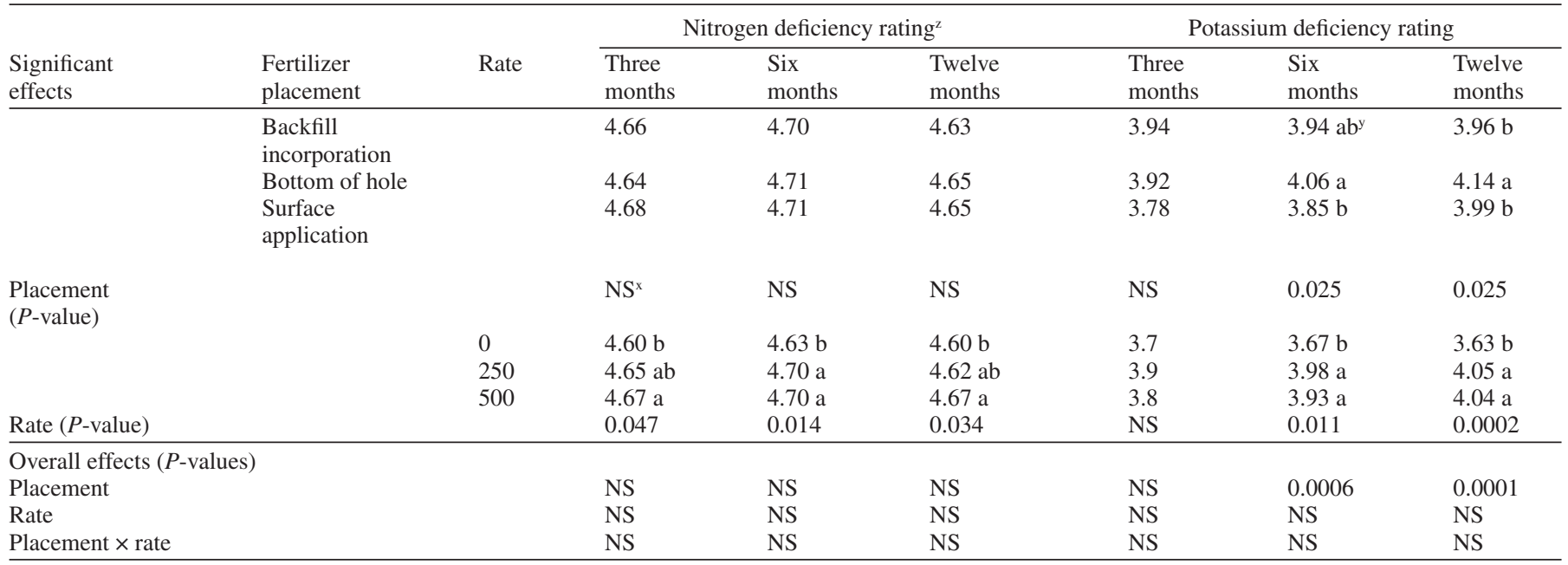

${ }^{\mathrm{z}}$ Ratings are on a 1 to 5 scale; 1 = severely deficient, 5 = no deficiency symptoms present.

${ }^{y}$ Mean separation within columns and fertilizer placement and rate groupings by the Waller-Duncan k-ratio method, $P=0.05$.

${ }^{x}$ Non-significant.

pling dates. In general, unfertilized palms always had the lowest $\mathrm{N}$ and $\mathrm{K}$ deficiency ratings, but palms receiving low and high fertilizer rates had equivalent deficiency ratings in Experiment 2

\section{DISCUSSION}

In general, fertilized areca palms transplanted from containers grew faster and had more roots than unfertilized palms, although the higher rate of fertilizer was usually no better than the lower rate. On the other hand, fertilizer placement effects were less pronounced and consistent. In Experiment 2, palms having fertilizers incorporated into the backfill at planting had a tendency to be taller and have more roots than those fertilized at the bottom of the hole or by surface application. This difference in root dry weight was due solely to the production of significantly more roots from the bottom of the root ball by palms with backfill-incorporated fertilizer. Downward leaching of nutrients from bottom-applied fertilizer could have removed nutrients from root contact prior to root extension from the bottom of the root ball into the soil below, which may have temporarily disadvantaged these plants. Differences in growth rate in container-grown palms due to fertilizer placement were not evident until six months or more following transplanting. This is likely due to the relatively slow growth of this species. Because the palms receiving no fertilizer at planting subsequently received the same fertilizer as the other treatments, long-term differences observed for shoot growth or root dry weight should be the result of fertilizer placement or rate treatments at the time of transplanting. The lack of significant differences in Experiment 1 shoot and root growth data may be because those palms were transplanted in October, versus March for Experiment 2 palms. Soil and air temperatures during the first four months following transplanting would have been much warmer in Experiment 2 than in Experiment 1. The fact that favorable responses to fertilization at transplant time were observed in this experiment may be due to the higher nutrient requirements of palms and the low fertility of the soil, compared to previous studies on broadleaf trees on other soils.
For transplanted field-grown areca palms, those receiving fertilizer at the bottom of the planting hole tended to have the highest $\mathrm{K}$ deficiency ratings (i.e., mildest deficiency symptoms) and root dry weights of any treatments. However, this was not the case with shoot growth rate, where fertilizer placement had no effect. The inconsistency of the response to fertilizer placement in field-grown areca palms suggests that fertilizer placement is not critical for good palm establishment and growth. However, fertilization rate at the time of planting strongly affected root dry weights, shoot growth rates, and $\mathrm{N}$ and $\mathrm{K}$ deficiency ratings, even twelve months later. Since the highest fertilization rate performed no better than the low rate, there appears to be no benefit to using a higher fertilization rate at the time of transplanting field-grown areca palms. This was also the case for areca palms transplanted from containers. Hensley et al. (1988) reported a similar response in container-grown Magnolia grandiflora with any fertilizer placement being superior to no fertilizer.

In conclusion, areca palms transplanted from containers grew best when fertilizer was incorporated into the backfill, but any fertilizer placement or rate was better than no fertilizer. Fieldgrown areca palms also benefited from fertilization at the time of transplanting, but fertilization method made no difference in palm growth or quality. Fertilization with a higher rate was no better than a lower rate for both container-grown and field-grown palms.

\section{LITERATURE CITED}

Broschat, T.K. 2011. Fertilization of field-grown and landscape palms in Florida. Univ. Florida Environmental Horticulture Department pub ENH1009.

Broschat, T.K., and K.A. Moore. 2010. Effects of fertilization on the growth and quality of container-grown areca palm and Chinese hibiscus during establishment in the landscape. HortTechnology 20:389-394.

Day, S.D., and J.R. Harris. 2007. Fertilization of red maple (Acer rubrum) and littleleaf linden (Tilia cordata) trees at recommended rates does not aid tree establishment. Arboriculture \& Urban Forestry 33:113-121. 
Elliott, M.L., T.K. Broschat, J.Y. Uchida, and G.W. Simone. 2004. Compendium of ornamental palm diseases and disorders. American Phytopathological Society Press, St. Paul, Minnesota, U.S.

Gilman, E.F. 1987. Response of hibiscus to soil applied nitrogen. Proceedings of the Florida State Horticultural Society 100:356-357.

Gilman, E.F., T.H. Yeager, and D. Kent. 2000. Fertilizer rate and type impacts magnolia and oak growth in sandy landscape soil. Journal of Arboriculture 26:177-182.

Harris, J.R., S.D. Day, and B. Kane. 2008. Nitrogen fertilization during planting and establishment of the urban forest: A collection of five studies. Urban Forestry \& Urban Greening 7:195-206.

Hensley, D.L., R.E. McNiel, and R. Sundheim. 1988. Management influences on growth of transplanted Magnolia grandiflora. Journal of Arboriculture 14:204-207.

Jacobs, D.F., K.F. Salifu, and J.R. Seifert. 2005. Growth and nutritional response of hardwood seedlings to controlled-release fertilizer at outplanting. Forest Ecology Management 214:28-39.

Perry, E., and G.W. Hickman. 1992. Growth response of newly planted valley oak trees to supplemental fertilizers. Journal of Environmental Horticulture 10:242-244.

Schulte, J.R., and C.E. Whitcomb. 1975. Effects of soil amendments and fertilizer levels on the establishment of silver maple. Journal of Arboriculture 1:192-195

Shoup, S., R. Reavis, and C.E. Whitcomb. 1981. Effects of pruning and fertilizers on establishment of bare root trees. Journal of Arboriculture 7:155-157.

Timothy K. Broschat (corresponding author)

University of Florida

Fort Lauderdale Research and Education Center

3205 College Avenue,

Davie, Florida 33314, U.S.

tkbr@ufl.edu

Kimberly A. Moore

University of Florida

Fort Lauderdale Research and Education Center

3205 College Avenue,

Davie, Florida 33314, U.S.
Zusammenfassung. Es wurden Areca-Palmen entweder aus Containern oder aus der Baumschule verpflanzt und mit einer Düngergabe versehen, die entweder auf den Grund des Pflanzlochs, in die Rückfüllerde eingearbeitet oder auf den Wurzelballen appliziert wurde, um den Einfluß von Düngung bei der Pflanzung von Palmen auf das Wachstum und Qualität zu bestimmen. Der Dünger wurde mit 0, $250 \mathrm{~g}(20 \mathrm{~g} \mathrm{~N})$ oder $500 \mathrm{~g}(40 \mathrm{~g} \mathrm{~N})$ pro Baum und Behandlung appliziert, um auch die Düngerrate zu bestimmen. Areca-Palmen aus Containern wuchsen am besten, wenn der Dünger in die Rückfüllerde eingearbeitet wurde, aber jede Düngergabe war besser als gar kein Dünger. Bei Areca-Palmen aus der Freifläche gab es keine eindeutig beste Dünger-Applikation. Dennoch wuchsen gedüngte Pflanzen besser und hatten weniger Mangelsymptome bei Stickstoff und Kalium als ungedüngte Pflanzen. Es gab keinen Vorteil von größeren Düngergaben sowohl bei Container- wie Freilandpflanzen.

Resumen. Palmas Areca (Dypsis bodinieri [(H. Wendl.) Beentje y j. Dransf]) fueron trasplantadas de contenedores o un vivero de campo y fueron tratados con fertilizante colocado en la parte inferior del hoyo de plantación, incorporado a la reposición, o en la superficie de la bola de raíz para determinar los efectos en el crecimiento y calidad de la colocación de fertilizante a plantar de la palma. El fertilizante se aplicó en $0,250 \mathrm{~g}(20 \mathrm{~g} \mathrm{~N})$, o $500 \mathrm{~g}(40 \mathrm{~g} \mathrm{~N})$ por árbol para cada método de colocación para determinar los efectos de la tasa de fertilización. Las palmas Areca trasplantadas de contenedores crecieron mejor cuando el fertilizante fue incorporado a la reposición, pero cualquier colocación de fertilizante o tasa fue mejor que ningún abono. Cuando las palmas areca fueron trasplantadas de un vivero de campo, no hubo ningún método de colocación de fertilizante consistentemente mejor. Sin embargo, plantas fertilizadas crecieron mejor y tenían síntomas menos graves de deficiencia de nitrógeno y potasio que palmeras no fertilizadas. No hubo ningún beneficio a la mayor tasa de fertilización para cualquiera areca cultivada en contenedor o en el campo. 